\title{
Digital Art: A Sourcebook of Ideas for Conceptualizing New Practices, Networks and Modes of Self-Expression
}

\author{
Vlad Strukov
}

\subsection{INTRODUCTION}

Computer-enabled, digital technologies have altered the ways in which art is produced, experienced and thought of. For example, in the 1990s, European, North American and Russian art museums and galleries developed multi-media products-Compact Discs (CD), Compact Disc Read-Only Memory (CD-ROM) and Digital Versatile Discs (DVD)—featuring images of artworks from their permanent collections along with critical commentary. The user was now able to appreciate works of art on the computer screen, and not just in the space of the gallery or in a book format. The user was also able to modify the image of an artwork, or add it to their personal web page, thus emerging as an "active" consumer of art. In the same period, online galleries appeared on the internet, competing with established institutions. In the early 2000s, online galleries emerged. For example, the Olga Gallery (abcgallery.com) was set up by teenage brothers Yury and Sergej Mataev, who published catalogued works by famous artists, first Russian and later world masters. Their clandestine gallery became an important teaching tool for those in the field of Russian Studies and Arts, providing easy access to quality reproductions of artworks.

At the same time, large museums started to provide online tours of their galleries. The Russian State Hermitage Museum was a pioneer of innovative virtual tours. On the one hand, the museum allows users anywhere in the

\footnotetext{
V. Strukov $(\bowtie)$

University of Leeds, Leeds, UK

e-mail: v.strukov@leeds.ac.uk

(C) The Author(s) 2021 
world to experience its galleries online. On the other, visitors to the museum in St. Petersburg can watch 3D movies and become a witness of historical events that had taken place in the Winter Palace. These experiments with virtual reality occurred at the same time as the production of Aleksander Sokurov's 2002 Russkij kovčeg (Russian Ark), a movie that was shot entirely in the Winter Palace of the Russian State Hermitage Museum on 23 December 2001 using a single-take single 96-minute Steadicam sequence shot. Russian Ark has become a digital artwork itself insofar as it had challenged existing theories of film and audio-visual presentation, paving the way for experiments with digital filmmaking in Hollywood and elsewhere. ${ }^{1}$ With the rise of social media in the late 2000s, museums started to use digital technologies, including providing immersive experiences so that the visitor can enjoy art across different platforms. Garage Museum of Contemporary Art in Moscow leads the way in terms of using digital technologies in its various inclusivity and access programs such as those for deaf people and people with visual impairments.

Digital technologies have changed the ways in which museums and galleries operate, including the kind of objects and practices they acquire for their collections. The debates about what constitutes art and how to collect, curate and exhibit it are ongoing. Digital art is commonly understood as a form of art produced, distributed and appreciated with the help of digital technologies. For the purpose of this chapter, I limit this definition to that kind of art which exists exclusively in the digital form. For example, an installation featuring objects, photographs and a digital component such as digital animation has been eliminated from my consideration. This process of elimination is not discriminatory but empowering because it makes one wonder about some principal notions helping us understand the nature and purpose of art. For example, is the digital a new medium or a new form of expression? Is digital just another way to say "contemporary"? Does the digital convey new forms of subjectivity or does it translate existing issues into a new "language"?

The discussion is based on the analysis of specific works of art, archival work, interviews with artists ${ }^{3}$ and critical assessment of exhibitions, biennales and festivals of contemporary art. The discussion is organized around two nodes: (a) historical and artistic contexts and (b) the scope and dynamics of Russian digital art. In the first instance, the chapter traces the evolution of digital technologies, artistic practice and cultural and aesthetic transformations. In the second instance, the chapter supplies a conceptualization of a diverse range of artworks around the notion of image transformation thanks to new digital technologies. All artworks and images discussed in the chapter are available in the public domain and so can be easily found in Wikimedia commons and other sites. 


\subsection{Re-structuring the Image: ${ }^{4}$ Olga Tobreluts and the Digital Collage (the 1980s and the 1990s)}

Computer technologies and digital literacy is one of the key components to a successful economy. This was recognized at the state level already in the 1980s under Soviet late socialism. Articulated as an imperative to develop new means of automation, the policy of digitalization was at the core of Mikhail Gorbachev's perestroika, which translates into English as "re-structuring." It aimed to supply new, more efficient means to carry out planning and management for the Soviet economy. It encompassed a development of a few generations of computers and computational technologies and a development of a workforce capable of operating complex machinery and running computer programs. These goals were achieved thanks to professional training made available to school pupils, students and those already in employment through re-training programs. As a result, in the late 1980s there was a large supply of engineers and other personnel involved in the production and maintenance of computer technologies (for more on digital education, see Chap. 10).

They were involved - often anonymously-in early experiments with computer art, or the application of algorithms capable of producing or copying artworks. These included, for instance, images rendering famous works of art with the help of zeros and ones, thus visualizing the computer code. Other experiments involved visualizations of mathematical formulas such as fractals. These are curves or geometrical figures, each part of which has the same statistical character as the whole. Fractals are used in modeling of complex structures such as snowflakes. On one level, digitally produced images incorporating and imitating fractal laws had the characteristics of geometrical patterns and so appeared as decorative elements. On another, they were works of art insofar as they enquired about the laws of the physical world and their mathematical representations, making references to abstract art and its predecessors such as the Russian avant-garde. These artworks were exchanged freely among communities of technical intelligentsia who experimented with computer technologies, moving beyond their utilitarianism and producing artworks. In doing so they embraced Gorbachev's neoliberal reforms such as unregulated information exchanges, the privatization of national resources and self-sufficiency.

The growing availability of computers and the emergence of new software such as Adobe Illustrator meant that artists started experimenting with digital art. In the early 1990s, in St. Petersburg, a young artist Olga Tobreluts (b. 1970) joined the art scene after making friends with Timur Novikov, an influential art manager and curator. At that time Novikov was pre-occupied with hangings made of different kinds of fabric and decorated with appliqués. These were "textile collages" aimed at re-organizing space in novel ways. Later he presented his ideas in the form of a theoretical treatise in which he called his visual experiments "perekompoziciâ" (re-compositions), a term which designates re-modeling and re-structuring of space (Andreeva 2007). Tobreluts 
responded to Novikov's ideas by making digital collages. She learned computer graphics and 3D modeling while on a visit to Berlin. On her return to St. Petersburg, she produced a series of images that featured digital "recompositions." They were shown at exhibitions in Russia, the United Kingdom (UK), the United States of America (USA) and other countries, securing Tobreluts the title of "a leading Russian digital artist" (Geusa 2013).

The novelty of her work was in the realistic "effect": instead of rejecting perceptive realism of classical art, Tobreluts utilized it to query the status of image and illusion in the digital era. For example, her project Models from the late 1990s consisted of re-interpretations of classical art for the digital era. Tobreluts followed the conventions of traditional portraiture by choosing a "head and shoulders," full face or three-quarter view, and depicting her subjects with a thoughtful expression of face. She enhanced the conventionality of her portraits by using sculptural elements available from antiquity. At the same time, Tobreluts challenged the viewers' perceptions by applying bright colors and making use of symbols from popular culture, for example, the Lacoste fashion brand. Ultimately, the artist enquired about the value of art and individual expression in the era of digital reproduction. Here originality stems from a "re-composition" of elements, not from new elements. Tobreluts "restructures" the artistic canon and the image itself by accentuating the composite quality of culture and memory. She conceives of digital art as a new medium, and by employing classical imagery she re-inscribes the digital into art history.

In an interview published in 1995, Tobreluts defines digital art in the following way. "First, the work is composed of different pieces. Then it is transferred from the computer to a compact disc $(\mathrm{CD})$. Then a negative is printed, and then a photograph is printed ... The computer is a stupid machine. It is just a metal box that can do nothing unless it is instructed to do something" 5 (Sharandak 1995). Tobreluts describes different stages in the production of a digital artwork whereby the digital is materialized, that is, different manipulations are used to present the digital as an object. Different stages in the production of the artwork refer to the process of layering employed in image editing programs such as Photoshop. Another artist-Natalia Kamenetskaia from Moscow-described the same process in an interview in 2011. Speaking of her digital collage titled St. Sebastian and produced in 1993 with the help of Photoshop, she notes that "St. Sebastian is a multi-layered, poly-semantic figure which brings together images and characters from classical and contemporary art" (Strukov 2011, 123-124). ${ }^{6}$

In her 1995 interview, Tobreluts conceived of computers and digital technologies as a new medium. She compared them to "a new kind of brush which is just more convenient to use" (Sharandak 1995). In my interview with her in 2017, Tobreluts spoke about "cifrovaâ èstetika" (digital visuality), or a particular way of thinking about the world, not just representing it artistically (interview with the author, 2017). In other words, in twenty years Tobreluts' understanding of computers and digitality has evolved from one which considers the digital as a more efficient medium to one which utilizes the digital to 
construct new worlds. The change in her thinking is manifested artistically: from using the digital to re-structure the image in the 1990s, in the 2010s she turned to using the medium of painting to reveal the nature and dynamics of the digital. I argue that this reversal of her artistic focus reveals the transformations propelled by the greater use of digital technologies in the present-day society.

In the early 1990s, Tobreluts, Kamenetskaia and other artists centered on the image as a key component of artistic expression. Their attempts to "restructure" the image using digital technologies resulted in a new understanding of artistic originality and authorship. Like their predecessors such as Marcel Duchamp, Andy Warhol and Ilya Kabakov, Russian digital artists queried art as an autonomous sphere of production. They continued to challenge the notion of the artistic genius by engaging with technologies that they could not fully control. ${ }^{8}$ Kamenetskaia acknowledges that "the computer was an unpredictable thing that would generate unplanned, unexpected results. Working with a computer was a mystical process" (Strukov 2011, 122-123). On one level, Kamenetskaia ascribes some degree of authorship to the machine which, in her view, is responsible for the outcome without discernible human intention. Like Dadaists, she embraces chance as a stimulus to expression in the work of art. Like Pollock, who practiced the technique called "Action Painting," which relied on chance, she is interested in random connections generated by the computer software.

On another level, Kamenetskaia re-claims ownership of art as a collective enterprise, thus opposing the long-standing tradition of perceiving art as a result of individual expression, or Romantic genius. She reminisces (Strukov 2011 ) that in the early 1990s she did not own her own computer and made use of her friends' computers, for example, of a computer that belonged to Irina Sandomirskaia, now a professor of Russian Studies at Södertörn University. Kamenetskaia would spend hours working on her computer at night. According to the artist, it was more than borrowing some tools from a friend; rather it was a collective enterprise insofar as they wanted to achieve something new in their work, namely, to open to the global community. Kamenetskaia recalls Sandomirskaia saying that "by learning how to use the computer we can show to the western world that we are part of it. The computer was a language in which all modern people communicated but Russians not yet" (Strukov 2011, 123). ${ }^{9}$ In this regard, Kamenetskaia and her friend, perhaps unknowingly, rehearsed the vision of global solidarity originally articulated by Sergei Eisenstein for the medium of film. For him, film would be a universal language, one that does not require translation, which would unite people of the world (2007 [1934]). 


\subsection{Re-Wiring the East: Olia Lialina ANd NeT.art (THE 1990s)}

These ideas of shared knowledge, collective authorship and international solidarity were at the core of an artistic movement known as net.art. The main members of the movement were Vuk Ćosić, Jodi.org, Heath Bunting, Aleksei Shulgin and Olia Lialina, based in countries that just a few years ago were separated by the Iron Curtain. To achieve a new post-Cold War commonality, they formed an artistic collective, defining their art as "net.art," or "internet art." Though they wished to explore similar political and social concerns, from the aesthetic standpoint their works were very different. Net.art is a synonym of "internet art." According to Shulgin, who allegedly coined the term, net.art stemmed from "conjoined phrases in an email bungled by a technical glitch (a morass of alphanumeric junk, its only legible term net.art)" (Greene 2004, 12). The term has been used in the title of various exhibitions celebrating internet art. It covers a wide range of artistic practices that use the internet as its main medium.

One of the most celebrated net.artists is Olia Lialina (b. 1971). She is widely recognized for developing the internet as a medium for artistic expression and storytelling. For example, her network-based artwork My Boyfriend Came Back from the War (1996) tells the story of a young woman and man who have been separated by war. To a Russian user, Lialina makes a reference to the first Chechen War, which had devastated the newly founded Russian Federation (RF); to other users, she speaks of a universal situation. The lovers attempt to engage in a conversation, but they find it difficult. It is not entirely clear whether they are communicating in the "real" or online world; the boundaries between spaces, lines of communication and identities are constantly blurred, creating a Chekhov-style drama of misunderstanding. Unlike other examples of net.art, My Boyfriend Came Back from the War is directly involved with the user's emotions. In fact, the work reflects on what constitutes expression, meaning and emotion on the internet. In many ways, it anticipated the conflicts and dramas of social media which are to appear a decade later.

My Boyfriend Came Back from the War makes use of interactive hypertext storytelling. The work consists of nested frames with black and white web pages and grainy GIF images that show human faces and objects. Lialina conceives of the internet as a space where the boundaries between words and images, and between connections and emotions, are erased. Each element is an arena of action, reflection and observation. When clicking hyperlinks in the work, the frame splits into smaller frames and the user reveals a nonlinear story about the couple. The story takes on a number of routes but eventually it leads to the point where the screen becomes a mosaic of empty black frames. They stand for emotional emptiness, a breakdown in communication and impossibility of genuine dialogue in the modern world (for more on hypertext, see Chap. 15). 
On one level, the squares and frames make a reference to the film strip, that is, a roll of frames. The grainy black-and-white images and intertitles evoke early silent movies. Like Eisenstein, Lialina is interested in montage as a means to construct meaning on the internet. On another level, the work reveals the potentialities of the internet as a new medium, particularly the role of the user in assembling data and constructing meaning. Without the user, the frames and images in My Boyfriend Came Back from the War would remain static. With the user's involvement they become animated. Here, reading the story is a ludic experience insofar as the user is guided but not directed to act, thus producing new connections and exploring new spheres of meaning. The user begins to wonder about their role and about the impact of their actions: are they there to observe an intimate conversation between a man and a woman? Are they responsible for the breakup of communication?

My Boyfriend Came Back from the War was displayed in Lialina's online gallery, which was one of the first internet-based galleries in the world. Nowadays artists employ the internet to produce, showcase and distribute their work, with many artists boasting profiles on numerous platforms. What Lialina has been interested in is the exploration of the possibilities of the new medium, on the one hand, and, on the other, the challenges of preserving early internet art and culture for future generations. With many programs now obsolete, how can a user experience the internet of the 1990s? Particularly, how can they feel the joy of connecting with someone they do not know in another country? This seems banal in the present-day world, but in the early 1990s with the world just emerging from the Cold War, being able to communicate directly with someone from another country was an extraordinary experience. What net.artists did in that period was to re-wire Europe and re-connect the world in new ways that would be free of government controls, ideological blocks and national, racial and gender stereotypes. My Boyfriend Came Back from the War is a record of this kind of aspiration of the post-Cold War Europe.

In her pioneering net.art, Lialina poses a number of important questions. The ethical ones are: what is the nature of communication? How does the internet change communication? What is privacy? How can we be intimate when there is no privacy? And the aesthetic questions are: what is duration on the internet? How do users define time? Does the digital have its own ontology? What kind of visuality and visibility does the digital supply? Is it possible to conserve the digital? In other words, My Boyfriend Came Back from the War and Lialina's other works are about knowledge and its calibrations and misnomers, about the scale and trajectory of communication and performance, and about the difference between connectivity and community. Lialina's works are simultaneously contextual-they exist within a specific technological and social context - and universal as they speak of global issues and assert universal values. 


\subsection{Mini and Maxi: Global Visions from Oleg Kuvaev AND AES+F (THE 2000s AND 2010s)}

While Lialina's works are significant from the standpoint of art criticism, history of communication and theory of the internet and the digital, they remain marginal from the standpoint of popular cultural industries and global consumption. Who were the artists who made digital art popular? Conversely, how did artists respond to the rise of popular use of digital technologies? What effects did the changes in technologies have on the aesthetics, distribution and significance of digital art? In this section, I aim to answer these questions by addressing two interrelated concerns. The first is the role of individual artists in the development of the cultural industry with its digital segment. The second is the transnational realm of Russian culture in general and digital art in particular. Indeed, my analysis of the works by Tobreluts and Lialina indicates that Russian digital art has been international from its inception. Here I wish to emphasize that it has always occupied a transnational domain. For instance, Tobreluts' collages signify the process of symbolic layering of culture in the era of globalization. She mixes tropes and forms stemming from different periods and contexts, and, following the imperial tradition of artistic expression such as the classical architecture of St. Petersburg, what makes her works Russian is the radical appropriation of seemingly un-Russian symbols. She reveals subjectivity through renouncing identities, or, to be precise, by demonstrating their constructed nature. With Lialina, transnational social networks define the processes of articulation and dissemination of her art. She works with artists based in other countries, and she makes art which is possible thanks to the actions of users located anywhere in the world. Lialina's interest in specificity and universalism points to the effects of global communication networks which, on the one hand, allow us to connect to anyone anywhere and, on the other, keep us trapped in our information bubbles. In addition, I argue that individual artists, not government-funded or corporate initiatives, are responsible for the emergence of cultural industry and digital economy in the RF.

The developments occurred at different levels and through employment of sundry strategies. Here I reflect on two of these, which I coded using the terms "mini" and "maxi." The former stands for a particular sense of intimacy, personal space, reflexivity and a steer toward abstraction (see the discussion of Lialina's works above). The latter signifies an infatuation with popular culture, spectacle and a steer toward figuration. To showcase the latter, I first investigate the work of Oleg Kuvaev before turning to the art collective known as AES $+\mathrm{F}$ (the name is initials of the artists Tatiana Arzamasova, Lev Evzovich, Evgenii Sviatskii and Vladimir Fridkes). Kuvaev's work characterizes the tendencies of the early 2000s while AES+F address the concern of the late 2000s and early 2010s.

In 2001, Kuvaev (b. 1967 in St. Petersburg) founded a small animation studio called Mult.ru and started promoting Masyanya, a series of short clips about the adventures of a young girl called Masyanya who lives in St. Petersburg 
with her boyfriend. Kuvaev worked with Macromedia Flash to produce films that were distributed over the network using viral marketing. Macromedia Flash uses vector technology to produced layered imagery. It appears quite simple - geometric lines, bright colors, lack of shading, and so on, but this simplicity, or rather naivety, was the key to success. In a few years, and in spite of Kuvaev being involved in a legal battle over his brand, ${ }^{10}$ Masyanya was the most popular phenomenon on the Russian language internet, linking communities in the RF, Europe, Israel, North America and elsewhere. Some describe the 2000s as "Putin's Russia" due to the rise of the new form of governance associated with the figure of the president (see, for example, Wegren 2018). I argue that the 2000s were "Masyanya's Russia" (see Strukov 2004 for full analysis) because Kuvaev and his Masyanya transformed the ways in which people communicated online, and gave rise to digital economy (for more, see Chap. 4$) \cdot{ }^{11}$

Kuvaev employs caustic humor and depicts Masyanya's absurd behavior while reflecting on the struggles of the young generation of Russians who had been affected by neoliberal reforms. Visually, Masyanya is an example of naïve, or primitive, art, that is, art that (looks as if it) was produced by non-professional artists. Elsewhere (Strukov 2004), I called Masyanya "a visual anecdote," meaning that the series functions as a digital form of joke-telling which has traditionally characterized Russian culture. Indeed, Masyanya has the qualities of humorous GIFs and memes, making it an alternative to commercial, mainstream culture. It is also a good example of how niche digital art may become popular. On the one hand, Masyanya resisted the dominance of Hollywood ${ }^{12}$ with its specific visual language and symbolic economy. On the other, it constructed its own alternative form of globalization based on principles of free labor, pirating and sharing. These practices have become commodified and commercialized since the emergence of Western social media giants such as Facebook and Instagram. Masyanya spoke of community, intimacy and honest conversation before they became catch phrases in the new global digital economy.

$\mathrm{AES}+\mathrm{F}$ are also interested in the effects of digital globalization on local communities. Their award-winning multi-channel digital video installation Allegoria Sacra (2011-2013) shows some passengers stranded in an international airport. The location alludes to Arthur Hailey's eponymous novel which has been hugely popular in Russia. It represents a global community stuck in some kind of temporal warp. The title of the video is of course a reference to Giovanni Bellini's painting (1490-1500) which represents the purgatory. Their artwork speaks of limbo and of the intemporality of the internet where everything is available forever and yet changes and disappears all the time. AES+F present a series of biblical figures, mythological creatures, cyborgs, clones and so on who are transposed into the eternal realm of Bellini's painting. Like Tobreluts, AES+F adopt classical forms for the digital environment when, for example, the Saracen-Muslim is transformed into a group of refugees and St. Sebastian turns into a young, shirtless traveler, hitchhiking his way through 
tropical countries. Yet, AES+F's artwork is more of an allegory of the contemporary life than a postmodern reinterpretation of Bellini's painting.

Allegoria Sacra weaves complex global issues such as the refugee crisis, global warming, identity politics, and gender and sexuality into visually rich metaphors. The group conceives of the digital as the element that holds the global society together. However, it is not clear whether this hold is a genuine bond or, in fact, a form of captivity. Like Lialina, AES $+\mathrm{F}$ are concerned with the issues of identity, privacy, freedom and choice. Allegoria Sacra reflects on human condition from a Russian yet global perspective. This global vision is accounted for by the artwork outreach-it has been shown at art venues all over the world-and it is encoded aesthetically through the use of a multiscreen projection which creates an extraordinary spectacle of performance and immediacy such as the slow digitally enhanced movement of characters and objects against the pulsating background. The massive scale of the project- the digital maxi-is also a reflection on the spectacularity of the digital, its omnipresence and panopticism. If Kuvaev ignited Russian digital economy by supplying a product that speaks of intimacy, community and commonality, AES+F showcase the might of this digital economy as they orchestrate a global show of connectivity and (mis)communication. All the artists address ethical and aesthetic questions posed by Lialina a decade ago, which suggests that these questions remain unanswered. This leads me to enquire about the legacy of digital art experiments in the RF.

\subsection{The Digital Archive: Cyland and Cyfest (the 2000s AND THE 2010s)}

After early experiments since the late 1980s, in the 2010s digital art has become a mainstay of Russian contemporary art scene. For example, there are art galleries that specialize in showing digital art, such as the Multimedia Art Museum headed by the diva of the Russian art scene Olga Sviblova and the Solyanka Art Gallery, which hires young curators to stage shows. Both are located in the center of Moscow and both are sponsored by the government. However, if the Multimedia Art Museum puts on big exhibitions showing blockbusters such as AES+F's Allegoria Sacra, for which the Museum gets sponsorship from Russian oil and gas monopolies, the Solyanka Art Gallery is a small space, hidden away from the tourist crowds and specializing in edgy, intellectually challenging exhibitions of international artists and artists from Russian regions. In addition to art spaces, there are numerous mergers - art and fashion as well as art and technology spaces - which include digital art in their programs. For example, Art Play Design Centre in Moscow stages immersive digital shows that enable the visitors to interact with artworks and digital environments. ${ }^{13}$ This type of exhibition does not engage with innovative technologies and complex issues; however, they do attract wider audiences to museum spaces, thus promoting digital art generally. Another example would be the use of digital art in popular 
culture, such as 3D projections and immersive videos during live concerts of the Ukrainian-born Russian singer Svetlana Loboda.

The burning issue facing Russian cultural managers is not the promotion of digital art but its preservation. Indeed, how does one conserve pieces produced using obsolete technologies like Lialina's My Boyfriend Came Back from the War? And how does one ensure that the Russian public, especially in Russian regions, remains aware of advances in digital art nationally and internationally? While these issues are being acknowledged in the professional community (Biryukova 2018), more work is needed in this direction. At present, no Russian national (federal) museum of digital art exists, and principal museums do not list digital art as their priority area in terms of acquisition. Three major institutions - the Hermitage, the Tretyakov Gallery and the Russian Museumhave departments specializing in contemporary art but acquisition of digital art is still very rare. This reveals a gap between artistic practices and the cultural economy whereby there is a perceived lack of national strategy in terms of promotion and preservation of digital art. For example, digital art does not feature in the nationally funded government-led program of digitalization of Russian economy introduced by President Dmitry Medvedev, and discussions in the Russian government and parliament tend to focus on digital literacy, which is, in fact, a re-hash of Gorbachev's policies of perestroika ("greater automation and greater efficiency"), and on digital security, which is in actual terms a string of legislation limiting freedoms of communication on the internet.

As a result, the arena of preservation of digital art has been occupied by private initiatives. One of the most influential ones is Cyland Media Lab. Founded in 2007, Cyland is a non-profit organization dedicated to digital art and broadly the intersection of art and technology through exhibitions, a collection of art, and educational programming. Overall, Cyland aims to connect emerging and established artists, educate how to use creative technology and foster innovation in new technologies (http://cyland.org/lab/about/). Co-founded by Marina Koldobskaia and Anna Frants, Cyland is sponsored by Frants, who, in addition to being a philanthropist, is an internationally renowned multi-media artist specializing in interactive art installations. Cyland collaborates with museums such as the Hermitage and the Chelsea Art Museum (New York, USA), but it has an ambition to build a museum of its own. For a decade Cyland has been building an online collection of artworks. Divided into a video archive and a sound archive, Cyland's online collection is a comprehensive survey of Russian and international art (over 100 individual artists and groups from the RF). Video and sound are understood as a means to categorize works, whereas in actual terms, the collection, managed by Viktoria Ilushkina, features video art, experimental films, computer graphics, 3D animation and so on. The collection reveals the technological, platform and genre diversity of what is understood as digital art.

In addition to an online collection, Cyland is committed to promoting digital art nationally and internationally through Cyfest. Running since 2008, Cyfest is an annual festival celebrating digital and new media art. The main part 
of the festival takes place at different venues in St. Petersburg, and some parts of the festival at exhibitions in partner institutions in London, New York, Venice and other places. As with similar festivals in other countries, Cyland festivals are themed; for example, in 2019 the theme was "ID," and in the previous year it was "Digital Cloudness." These themes refer to pressing social, political and aesthetic concerns in the contemporary world. Unlike Ars Electronica in Linz, Austria, Cyfest is a much more focused enterprise with a commitment to experimentation and community building, and not city branding and industry collaborations. Cyfest remains the principal platform for showcasing experimental digital art in the RF. The legacy of Cyland and similar initiatives is to be assessed in future research.

On the one hand, Russian digital art is frequently presented at international art festivals such as Cyfest. On the other, a national museum or archive of computer-based and digital art is to be formed. This is highly unusual for a country obsessed with museums and museufication. In fact, digital artworks are still to be included in permanent collections of existing museums such as the Russian Museum in St. Petersburg and the Tretyakov Gallery in Moscow. Similarly, a history and a theory of Russian digital art and new media art are to be written. In this context of research possibilities and probabilities, an essential history of Russian art allows for an in-depth understanding of the development of internet technologies in the RF (for more on types of digital archives, see Chaps. 20 and 21).

Nowadays the internet is a mundane thing and users are more likely to speak of specific platforms such as VKontakte or Twitter. In the mid-1990s the internet was a novel phenomenon which relied on the user's advanced technical knowledge and produced an important effect of instantaneous connectivity in a world where people still used landline telephone connections, faxes and telegrams to communicate with each other. Indeed, instantaneity of communication and production of online social networks were two focal points of net. artists. They employed a variety of techniques some of which would be considered dubious by present-day users, such as fake websites, spam mails and unsolicited distribution of information. Their purpose was to explore networked modes of communication and interplays of exchanges. They understood collaborative and cooperative work differently whereby they frequently delegated the production of the artwork to the user, not just to other members of the artistic community. Ultimately, they aimed at working across national borders, building a digital utopia for the next generation of artists. For many contemporary Russian artists, the digital remains an arena of utopian possibilities to be explored.

\section{Notes}

1. For an in-depth discussion of the film, see Strukov (2009).

2. On new media as a form of language, see Manovich (2001). 
3. Some of these interviews were published in Studies in Russian, Eurasian and Central European New Media; see, for example, Strukov (2011).

4. In Russian, "perestroika obraza."

5. [Vse montiruetsâ iz raznyh kusočkov. Potom s komp’ûtera peregonâetsâ na lazernyj disk. Pečataetsâ negativ, potom s nego-fotografiâ.... Komp’ûtery-oni že glupye mašiny. Metalličeskaâ korobka, kotoraâ nič̌ego ne možet sdelat”, esli ty ej ne skažeš', čto nužno sdelat'].

6. [“Svâtoj Sebast'ân—èto rabota, v kotoroj sloi kul'tury naslaivaûtsâ. Èto mnogoslojnyj, mnogoznačnyj obraz, gde soedinâûtsâ personaži sovremennogo iskusstvasovremennogo tomu vremeni-i klassičeskie personaži].

7. [Ran'se, kogda pisali kartiny, poâvlâlas' novaâ kist', bolee udobnaâ, nikto že ot nee ne otkazyvalsâ].

8. [Komp'ûter byl dlâ menâ istočnikom raznyh neožidannyh vêsej, kogda ty čto-to delaeš', i polučaetsâ nezaplanirovannyj rezul'tat. Kakoj-to mističeskij daže process].

9. [Â pomnû frazu Sandomirskoj, kogda poâvilsâ komp'ûter, čto èto očen' važno, čto my osvoili komp'ûter, potomu čto my pokazali zapadnomu miru, čto my čast' ètogo mira. To est' èto byl âzyk, na kotorom govorili vse sovremennye lûdi, a Rossiâ êse net].

10. Kuvaev lost and in the end decided to emigrate to Israel.

11. In retrospect, it is possible to interpret Masyanya's adventures as a parody on Putin, who is also from St. Petersburg.

12. See Norris (2012) and Strukov (2016) on the dominance of Hollywood aesthetics on Russian culture in the 2000s.

13. See, for example, their recent Samskara project (https://www.samskara.pro/ [10.10.2019]).

\section{REFERENCES}

Andreeva, Ekaterina. 2007. Postmodernizm: Iskusstvo vtoroj poloviny 20-go - načala 21-go veka [Postmodernism: The Art of the Second Half of the 20th - Beginning of the 21st Century]. Moscow: Azbuka-Klassika.

Biryukova, Svetlana. 2018. Iskusstvo interakcii [The Art of Interaction]. Accessed October 10, 2019. http://rusmuseum.ru/pavilions-mikhailovsky-castle/news/ march-27-from-16-00-to-21-00-at-the-media-centre-held-a-roundtable-on-theart-of-interaction-from-co/.

Eisenstein, Sergei. 2007. Writings, 1934-1947. London: I.B.Tauris.

Geusa, Antonio. 2013. Russian Digital Artist Olga Tobreluts Gets Huge Retrospective at Moscow Museum of Modern Art. Phaidon. Accessed October 10, 2019. https:// uk.phaidon.com/agenda/art/articles/20l3/january/25/ russian-digital-artist-olga-tobreluts-gets-huge-retrospective-at-moscow-museumof-modern-art/.

Greene, Rachel. 2004. Internet Art. London: Thames \& Hudson.

Manovich, Lev. 2001. The Language of New Media. Cambridge, MA: The MIT Press.

Norris, Stephen. 2012. Blockbuster History in the New Russia: Movies, Memory, and Patriotism. Bloomsbury: Indiana University Press.

Sharandak Natalya. 1995. Komp'ûternyj akademizm [Computer Academism]. Accessed October 10, 2019. http://www.owl.ru/win/books/sharandak/11.htm. 
Strukov, Vlad. 2004. Masiania, or Reimagining the Self in the Cyberspace of Rusnet. The Slavic and East European Journal 48 (3): 438-461.

. 2009. A Journey through Time: Alexander Sokurov's Russian Ark and Theories of Mimesis. In Realism and the Audiovisual Media, ed. Lucia Nagib and C. Mello, 119-132. London: Palgrave Macmillan.

- 2011. Digital Sebastian: Interview with Natalia Kamenetskaia. Studies in Russian, Eurasian and Central European New Media 6: 121-127.

- 2016. Contemporary Russian Cinema: Symbols of a New Era. Edinburgh: Edinburgh University Press.

Wegren, Stephen. 2018. Putin's Russia: Past Imperfect, Future Uncertain. Lanham: Rowman \& Littlefield.

Open Access This chapter is licensed under the terms of the Creative Commons Attribution 4.0 International License (http://creativecommons.org/licenses/ by/4.0/), which permits use, sharing, adaptation, distribution and reproduction in any medium or format, as long as you give appropriate credit to the original author(s) and the source, provide a link to the Creative Commons licence and indicate if changes were made.

The images or other third party material in this chapter are included in the chapter's Creative Commons licence, unless indicated otherwise in a credit line to the material. If material is not included in the chapter's Creative Commons licence and your intended use is not permitted by statutory regulation or exceeds the permitted use, you will need to obtain permission directly from the copyright holder. 